University of Nebraska - Lincoln

DigitalCommons@University of Nebraska - Lincoln

Faculty Publications from the Department of Electrical \& Computer Engineering, Department Electrical and Computer Engineering

4-15-1997

\title{
In-situ ellipsometric control of magnetic multilayer deposition (abstract)
}

Xiang Gao

University of Nebraska-Lincoln

Scott Heckens

University of Nebraska-Lincoln

John A. Woollam

University of Nebraska-Lincoln, jwoollam1@unl.edu

Follow this and additional works at: https://digitalcommons.unl.edu/electricalengineeringfacpub

Part of the Electrical and Computer Engineering Commons

Gao, Xiang; Heckens, Scott; and Woollam, John A., "In-situ ellipsometric control of magnetic multilayer deposition (abstract)" (1997). Faculty Publications from the Department of Electrical and Computer Engineering. 63.

https://digitalcommons.unl.edu/electricalengineeringfacpub/63

This Article is brought to you for free and open access by the Electrical \& Computer Engineering, Department of at DigitalCommons@University of Nebraska - Lincoln. It has been accepted for inclusion in Faculty Publications from the Department of Electrical and Computer Engineering by an authorized administrator of DigitalCommons@University of Nebraska - Lincoln. 


\section{In-situ ellipsometric control of magnetic multilayer deposition (abstract)}

Xiang Gao, ${ }^{\text {a) }}$ Scott Heckens, and John A. Woollam

Center for Microelectronic and Optical Materials Research, and Department of Electrical Engineering, University of Nebraska, Lincoln, Nebraska 68588-0511

Correct determination of layer thicknesses on a subnanometer scale is crucial for studies of giant magnetoresistance, magneto-optical (MO) Kerr rotation, magnetic interlayer coupling, and other magnetic properties of metallic multilayers. Some structures such as $[\mathrm{Co} / \mathrm{Ni}]$ and $[\mathrm{Co} / \mathrm{Pt}]$ with fewer than 20 repeats are difficult to be analyzed by x-ray diffraction (XRD) due to too little material. In this work, in-situ spectroscopic ellipsometry (in-situ SE) is used to precisely determine the optical constants undisturbed by oxidation, and the growth rates of different metal films deposited in a sputtering chamber. In-situ SE determines both the constant and continuously changing growth rates during deposition of individual layers. SE data were also taken during multilayer thin-film growth, from which we determine the individual layer thicknesses in the superlattice to a fraction of an angstrom. The in-situ SE data and ellipsometric analysis of $[\mathrm{Co} / \mathrm{Au}]$ and $[\mathrm{Co} / \mathrm{Ni}]$ multilayers on thick gold-coated silicon, and $[\mathrm{Co} / \mathrm{Pt}]$ multilayers with a Pt underlayer are presented. Less than a few percent difference was found by comparing the XRD thickness results to the in-situ SE thickness results. In-situ SE permits studies of oxidation kinetics, important because oxidation strongly influences both the magnetic and MO results. Specifically, spectroscopic MO Kerr rotation, ellipticity, and figure of merit of $[\mathrm{Co} / \mathrm{Ni}]$ and $[\mathrm{Co} / \mathrm{Pt}]$ multilayers with different repeat structures, with and without capping layers are reported covering the spectral range from ultraviolet to near infrared. (C) 1997 American Institute of Physics. [S0021-8979(97)82608-4]

Research supported by NSF Grant Nos. OSR-9255225 and DMR-9222976.

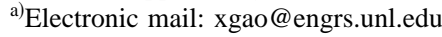

